\title{
The linkage between knowledge management practices and company Performance: empirical evidence
}

\author{
Nausheen Syed, Lin Xiaoyan \\ School of economics and management, Beijing Jiaotong university (China) \\ nausheeniba@yaboo.com,xylin611@,163.com
}

Received: October 2012

Accepted: August 2012

\section{Abstract:}

Purpose: This study explores the linkage between Knowledge management practices and company performance. Keeping in view the theoretical and empirical importance, the present study examines the predicting linkage of Knowledge management practices (sharing of best practices and building of consistent process, continues employee learning, effective management of knowledge, innovative culture development, and management of core competencies) with company performance.

Methodology: The study was carried out on purposively selected sample of 412 employees at different managerial positions. They were administered questionnaires including Knowledge Management Practices and company performance. Data was operated by using SPSS version 20.Correlation and regression analysis was done to establish the relationship between various Knowledge management practices and company performance.

Findings: Results of this study illustrated that all selected Knowledge management were positively related to company performance. Based on the findings, and management of core competencies was the strongest predictor of company performance, followed by innovative culture development, effective management of knowledge and sharing of best practices and building of consistent process, continues employee learning.

Research limitations/implications: The paper focuses on examining the perceptual impacts of Knowledge management (KM) practices on company performance. The interpretation of results should be taken with caution. 
Value: The aim of this research is to investigate the relationship between Knowledge management and company performance, study the importance of Knowledge management as a source of sustainable competitive advantages for companies and to investigate how the introduction of Knowledge management practices facilitates company performance to improve. The practices that have a more positive influence on company performance are also discussed.

Keywords: Knowledge management practices, Company performance, Pakistan, Innovative culture, Core competencies.

\section{Introduction}

Knowledge management has appeared as one of the most vital part in management practices and founded as a basic resource for companies and economies. As organizations became aware of the power of knowledge as the most valuable strategic resource in the knowledge economy, Knowledge management became widely recognized as essential for the success or failure of organizations. Knowledge management is the process of converting information and intellectual assets into lasting value. It unites people with the knowledge that they require to take action, while they need it. From a business viewpoint, knowledge seems to be a main aspect for a company success in the long run (Mansell \& When, 1998; Stewart, 2001; Tat \& Stewart, 2007). The aim of this research is to investigate the relationship between Knowledge management and company performance, study the importance of Knowledge management as a source of sustainable competitive advantages for companies and to investigate how the introduction of Knowledge management practices facilitates company performance to improve. This link was examined in Pakistan environment, which is at the beginning of recognizing a market-based economy and where most of companies are only beginning to integrate Knowledge management into their business philosophy. This research shows the result of a survey which was carried out in 52 Pakistani companies. This research identified the Knowledge management practices that potentially affect company performance.

\section{Literature Review}

Today, the main worldwide pressure on management practices is knowledge recognition, formation, innovation, propagation, and development of talent. The basics of economic competition have shifted in important ways in recent years because of the force of globalization, abundance of information technology, the availability of information and the changing nature of organizational forms. In a market where the only certainty is uncertainty, the one convinced source of enduring competitive advantage is improved knowledge management (Nonaka, 1994).Various empirical studies focus only on specific characteristic of 
knowledge management, not the whole knowledge management system, such as (Lee, Lee \& Kang, 2005) were estimating the performance of company with respect to its knowledge, and (Harlow, 2008) assessing the level of tacit knowledge within company and its effect on company performance. (McKeen, Zack \& Singh, 2006) Concluded that Knowledge management practices are directly related to organizational performance which, in turn, is directly related to financial performance. Feng, Chen and Liou, (2004) investigated that Knowledge management systems improve company performance by considerably dropping administrative costs and improve productivity in the second year after implementing knowledge management system. The present research is divided into three major parts. The first part deals with the concept of Knowledge management and its practices and the second part presents methodology and data analysis. Finally, the third part discusses results/findings and conclusion.

For the purpose of this study, the following hypotheses have been formulated.

\subsection{Knowledge sharing practices and building of consistent process}

Knowledge sharing is a process between the individuals which can not be seen nor observed (Ryu, Hee \& Han, 2003). Van den Hooff, Elving and Dumoulin (2003) Defined knowledge sharing as a process where individuals exchange knowledge and together create new knowledge. Many researchers admitted that there are many concepts that support the relationship between knowledge sharing, data consistencies, employee learning and company performance. But empirical research is limited. There are few research studies that try to identify the relationship between knowledge sharing, data consistencies, employee learning and company performance. Based on these discussion following hypothesis is proposed

Hypothesis 1: There is a positive linkage between the Knowledge sharing and building of consistent process in organization with company performance.

\subsection{Continues employee learning}

Continues employee learning is the process of developing actions through better knowledge and understanding" (Fiol \& Lyles, 1985). According to Appelbaum and Reichart (1998) analysis the organization as a learning system and focus on three important uniqueness of a learning organization. These are the learning process, the learning orientation, and the facilitating factors within the company. Companies give both formal and informal processes and structures for acquisition, sharing and use of knowledge and skills. Fostering a learning culture within organizational boundaries persuades employees to continually learn from each other (Becerra-Fernandez, Gonzalez \& Sabherwal, 2004). Moreover, employees will adjust their information needs according to new changes in the business environment. Employees' commitment to learning and motivation to learn new knowledge and skills not only improve an organization's competitive advantage but also promote ongoing success (Tat \& Stewart, 2007). 
Hypothesis 2: There is positive and significant linkage between continues employee learning of the knowledge and company performance.

\subsection{Effective management of knowledge}

Effective management of the knowledge is very important for success of company. According to Clarke and Rollo (2001) knowledge management is based on "applying the comprehensiveness of an organization's knowledge to its decisions and this involves hard working to characterize it, transfer it, make it available and persuade its use. None of this occurs automatically, it takes time and dedication. Though, it's not possible to say that all knowledge management programs have accomplished the desired results. (Alavi, M. \&Leidner, 2001) have revealed that understanding the attributes and the relationship with the approaches of knowledge creation is significant to improve organizational knowledge creation. Accordingly, the following hypothesis is proposed.

Hypothesis 3: There is positive and significant linkage between effective management of the knowledge and company performance.

\subsection{Innovative culture development practice}

Firms can achieve a competitive advantage over the other firms when they acquire knowledge which is firm specific and if they handle knowledge in a way that is difficult to imitate (Earl, 2001). Innovation is treated as a strategic preference; a firm's actions that are an outcome of its characteristics and determinant of firm performance (Kaul, 2002). Innovative culture is a type of adaptive and exterior positioning since it stresses on innovation and nurtures internally based capabilities in order to acknowledge new ideas, processes, products, and brands.

Hypothesis 4: There is positive and significant linkage between developments of innovative culture that give competitive advantage and company performance.

\subsection{Management of Core Competency Development}

Core competence is the knowledge set that differentiates a firm and offers a competitive advantage over others (Leonard-Barton, 1992). Core competencies when analyzed as inimitable knowledge for problem definition and problem solving can form the basis of a firm's competitive advantage and can also be influenced in a wide variety of markets for future products (Srivastava, 2005). Core competencies are expertise and areas of knowledge that are shared across business units and result from the incorporation and coordination of small business units competencies. Hamel and Prahalad (1994) argue that "core competencies are the mutual learning in the companies, mostly how to organize various production skills and integrate multiple flows of technologies." They argue that core competence is communication, contribution, and a deep assurance to working across organizational boundaries. 
Hypothesis 5: There is positive and significant linkage between management of core competency development that give competitive advantage and company performance.

\section{Results and Discussion}

\subsection{Correlation Analysis}

The results of correlation analysis are in Table 1. Range of correlation between Knowledge management practices is between 0.895 to 0.150 . All variables have positive relationship and statistically significant at $(p<0.001)$.

\begin{tabular}{|c|c|c|c|c|c|c|}
\hline Variables & SP\&BC & CEL & EMK & ICD & $\mathrm{MCC}$ & $\mathrm{CP}$ \\
\hline SP\&BC & 1 & & & & & \\
\hline CEL & $.271 * *$ & 1 & & & & \\
\hline EMK & $.227 * *$ & $.239 * *$ & 1 & & & \\
\hline ICD & $.150 * *$ & $.635 * *$ & $.370 * *$ & 1 & & \\
\hline $\mathrm{MCC}$ & $.300 * *$ & $.895 * *$ & $.379 * *$ & $.567 * *$ & 1 & \\
\hline $\mathrm{CP}$ & $.434 * *$ & $.350 * *$ & $.296 * *$ & $.190 * *$ & $.374 * *$ & 1 \\
\hline
\end{tabular}

Table 1. Pearson correlation between knowledge management practices and company performance (SP\&BC: sharing of best practices \& building of consistent process; CEL: Continues employee learning; EMK: Effective management of knowledge; ICD: Innovative culture development; MCC: Management of core competencies: CP: Company performance)

\section{Conclusions}

The need of knowledge management begins when knowledge is created and subsequently shared. The empirical evidence presented here suggests that sharing of best practices, building of consistent process and management of core competency are the most important Knowledge management practices, for the small/medium and large telecommunication and pharmaceuticals companies in Pakistan, that can facilitate knowledge management success having a significant impact on firm performance. Companies that facilitate knowledge management and promote effective knowledge practices transfer today will have competitive advantage tomorrow.

\section{References}

Alavi, M., \& Leidner, D.E. (2001). Review, Knowledge Management and Knowledge Management Systems: Conceptual Foundations and Research Issues. MIS Quarterly, 25, 107136. http://dx.doi.org/10.2307/3250961

Appelbaum, S., \& Reichart, W. (1998). How to measure an organizations' learning ability: The facilitating factors - part II. Journal of Workplace Learn, 10, 15-25. http://dx.doi.org/10.1108/13665629810370012 
Becerra-Fernandez, I., Gonzalez, A., \& Sabherwal, R. (2004). Knowledge management: Challenges, solution, and technologies. Upper Saddle River, NJ: PrenticeHall.

Earl, M. (2001). Knowledge management strategies (2001).Towards taxonomy, Journal of Management Information system, 18, 215-233.

Fiol, C.M., \& Lyles, M.A. (1985).Organizational learning. Academy of management Review, 10, 803-813.

Feng, K., Chen, E.T., \& Liou, W. (2004). Implementation of knowledge management systems and firm performance: an empirical investigation. Journal of Computer information system, 45, 92-104.

Harlow, H. (2008). The effect of tacit knowledge on firm performance. Journal of Knowledge Management, 12, 148-163. http://dx.doi.org/10.1108/13673270810852458

Hamel, G., and Prahalad, (1994). The concept of core competence. In Hamel, G. \& Heene, A. (Eds), Competence-Based Competition. New York, NY: Wiley, 11-16.

Kaul, V.K. (2002). Knowledge management and innovation in technology based small and medium sized enterprises. Management Result News, 25, 8-10.

Lee, K.C., Lee, S. \& Kang, I.W. (2005). KMPI: measuring knowledge management performance. Information \& Management, 42, 469-482. http://dx.doi.org/10.1016/j.im.2005.10.003

Leonard-Barton, D. (1992). Core capabilities and core rigidities: A paradox in managing new product development. Strategic Management journal, 13, 111-125. http://dx.doi.org/10.1002/smj.4250131009

Mansell, R., \& When, U. (1998). Knowledge Societies: Information Technology for Sustainable Development. New York: Oxford University.

McKeen, J.D., Zack, M.H., \& Singh, S. (2006). Knowledge Management and Organizational Performance: An Exploratory Survey. Proceedings of the $39^{\text {th }}$ Annual Hawaii International Conference on System Sciences. Computer Society Press, Hawaii, 9 pages. http://dx.doi.org/10.1109/HICSS.2006.242

Nonaka, I. (1994). A dynamic theory of organizational knowledge creation. Organizational Science, 5, 14-37. http://dx.doi.org/10.1287/orsc.5.1.14

Ryu, S., Hee, H.S., \& Han, I. (2003). Knowledge sharing behavior of physician in hospitals. Expert system with application, 25,113-122. http://dx.doi.org/10.1016/S09574174(03)00011-3 
Srivastava, S.C. (2005) .Managing Core Competence of the Organization. Vikalpa, 30, 49-68.

Stewart, T. (2001).The Wealth of Knowledge: Intellectual Capital and the Twenty-First Century Organization. Doubleday, Random House Inc., U.S.A.

Tat, L.W., \& Stewart, H. (2007). Knowledge Management in the Malaysian Aerospace Industry. Journal of Knowledge Management, 11, 143-151. http://dx.doi.org/10.1108/13673270710728295

Vestal, W. (2002). Measuring Knowledge Management. From Providers Edge Web site: http://www.providersedge.com/docs/km articles/Measuring_KM.pdf

Van den Hooff, B., Elving, W.J.L., Meeuwsen, J.M., \& Dumoulin, C.M. (2003). Knowledge sharing in knowledge communities. In Huysman, M.H., Wulf, V. \& Wenger, E. (Eds.). Communities and Technologies. Deventer: Kluwer Academic Publishers, 119-142.

Journal of Industrial Engineering and Management, 2013 (www.jiem.org)

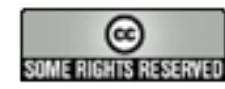

El artículo está con Reconocimiento-NoComercial 3.0 de Creative Commons. Puede copiarlo, distribuirlo y comunicarlo públicamente siempre que cite a su autor y a Intangible Capital. No lo utilice para fines comerciales. La licencia completa se puede consultar en http://creativecommons.org/licenses/by-nc/3.0/es/ 